\title{
APPLICATION OF THEORY OF GENRES IN TACKLING PROFESSIONAL MEDICAL DISCOURSES
}

\author{
Kozka I.K., PhD in Philology, \\ Krasnikova S.O., PhD in Philology (Kharkiv)
}

The article deals with the issues of the application of the theory of genres while handling professional medical discourses. The practical implementation of the theory of genres in learning a professional medical discourse is one of the efficient techniques in current methodology of teaching English. The topicality of the research is determined, firstly, by the fact that different genres are commonly used in the practice of medical professional interaction and the domain of a foreign language teaching in a medical language classroom. Secondly, there is a need to outline grammar and lexical peculiarities of the genres of medical discourses and their functioning in oral and written speech. The authors study the problems of the theory of genres concerning medical discourses. The researchers characterize the main lexical and grammar peculiarities of the genre of an oral presentation of a patient's medical history, the genre of a scientific text for the specialty "Technologies of Medical Diagnosing and Treatment”, the genre of a letter of referral to a medical specialist and reveal specific features of their functioning in oral and written speech. Linguistic analysis of a medical discourse which is focused on lexical, grammatical, functional and rhetoric peculiarities of a written or an oral discourse appears to be very fruitful allowing us to answer the questions how tests are structured and organized. Textual success often depends on the familiarity of text organization for readers of the discourse community, however small or large that community might be and students should be aware of the genre norms. Dealing with professional medical genres, we assume that every genre is clearly structured and has its own sets of language structures. The task of language instructors is to acquaint the learners with existing genre norms. The authors have singled out the "moves" of the three genres and developed the sequence of pre-reading, while-reading, post-reading and information gap activities which are effective while working on the discourses that have been studied.

Key words: communicative purpose, discourse, genre analysis, medical community, peculiarity.

Козка І.К., Краснікова С.О. Використання теорії жанру при роботі над професійними медичними дискурсами. Робота розглядає питання використання теорії жанрів при роботі 3 професійними медичними дискурсами. Практичне використання жанрового аналізу в навчанні $\epsilon$ одним із ефективних засобів у сучасній методиці викладання англійської мови. Актуальність дослідження визначається, по-перше, тим, що різні жанри широко використовуються у практиці медичного професійного спілкування та у сфері навчання іноземної мови студентів-медиків. По-друге, існує потреба визначити лексико-граматичні особливості медичних дискурсів та їх функціонування в усному та письмовому мовленні. Автори досліджують питання теорії жанрів стосовно медичних дискурсів, аналізуючи такі жанри: жанр усного представлення історії хвороби

(C) Kozka I.K., Krasnikova S.O. 2020 
пацієнта, жанр наукового тексту для спеціальності «Технології медичної діагностики та лікування», жанр довідки-направлення пацієнта до лікаряспеціаліста, та виявляють особливості їх функціонування у мові. Працюючи над медичними дискурсами, ми виходимо 3 того, що кожен жанр чітко структурований та використовує специфічні мовні засоби. Лінгвістичний аналіз медичного дискурсу допомагає висвітлити питання стосовно того, як тексти структуровані та організовані. Успіх навчання залежить від того, наскільки користувачі медичних дискурсів та члени медичної спільноти знайомі зі структурою та організацією текстів. Завдання викладача- навчити студентів використовувати ці жанрові норми. Автори виокремили конституенти трьох жанрів та розробили послідовність дотекстових, текстових, післятекстових завдань та вправи на заповнення «інформаційних прогалин», які є ефективними при роботі над досліджуваними дискурсами.

Ключові слова: дискурс, жанровий аналіз, комунікативна мета, медична спільнота, особливість.

Козка И.К., Красникова С.А. Использование теории жанра при работе над профессиональными медицинскими дискурсами. В статье рассмотрены вопросы использования теории жанра при работе над профессиональными медицинскими дискурсами. Практичное использование жанрового анализа в обучении является одним из эффективных приемов в современной методике преподавания английского языка. Актуальность исследования обусловлена, вопервых, тем, что разные жанры широко используются в практике медицинского профессионального общения и в сфере изучения иностранного языка студентамимедиками. Во-вторых, существует потребность выявить лексико-грамматические особенности медицинских дискурсов и их функционирования в устной и письменной речи. Авторы исследуют вопросы теории жанров относительно медицинских дискурсов, анализируя жанр устной презентации истории болезни пациента, жанр научного текста для специальности «Технологии медицинской диагностики и лечения», жанр справки-направления пациента к врачуспециалисту, и выявляют особенности их функционирования в речи. Работая над медицинскими дискурсами, мы исходим из того, что каждый жанр четко структурирован и использует специфические языковые средства. Лингвистический анализ медицинского дискурса помогает осветить вопросы относительно того, как тексты структурированы и организованы. Успех обучения зависит от того, насколько пользователи медицинских дискурсов и члены медицинского сообщества знакомы со структурой и организацией текстов. Задача преподавателя - научить студентов использовать эти жанровые нормы. Авторы выделили конституэнты трех жанров и разработали последовательность дотекстовых, текстовых, послетекстовых заданий и упражнений на заполнение информационных пропусков, являющихся эффективными при работе над анализируемыми дискурсами.

Ключевые слова: дискурс, жанровый анализ, коммуникативная цель, медицинское сообщество, особенность.

The practical implementation of the theory of genres is one of the efficient techniques in current methodology of teaching English for special purposes. This especially concerns gaining medical proficiency 
in English, when a current life asks for a thorough command of a foreign language in performing professional work by medical specialists. Medical discourses are efficiently used in academic and professional settings. There are a lot of professional genres in a medical communication. And the task of the teachers is not only to facilitate students' linguistic command but also promote their medical proficiency. Genre theory has been studied by many scientists. Such researchers as V.K. Bhatia, T. Dudley-Evans, J. Swales, A. Freedman, T.A. Upton, K. Hyland, C. Miller, R.M. Coe have made a lot of research in this field of linguistics and analyzed structural, functional and pragmatic peculiarities of genres.

The topicality of the research is determined, firstly, by the fact that different genres are commonly used in the practice of medical professional interaction and the domain of a foreign language teaching in a medical language classroom. Secondly, there is a need to outline grammar and lexical peculiarities of the genres of medical discourses and their functioning in oral and written speech in order to know the rules according to which medical discourses are structured and organized.

The object of the research includes the genre of an oral presentation of a patient's medical history, the genre of a scientific text for the specialty “Technologies of Medical Diagnosing and Treatment” and the genre of a letter of referral. The subject of the research covers lexical and grammatical features of these genres and peculiarities of their functioning in oral and written speech.

The aim of the article is to characterize lexical and grammar peculiarities of the genre of an oral presentation of a patient's medical history, the genre of a scientific text for the specialty "Technologies of Medical Diagnosing and Treatment" and the genre of a letter of referral, to reveal specific features of their functioning and to develop the sequence of meaningful activities.

The presentation of the material. According to V.K. Bhatia, although genre analysis is a relatively recent development in the field of applied discourse studies, it has become extremely popular in the last few years [5: 629]. The researcher states that genre theory extends discourse analysis from linguistic description to explanation, often attempting to answer the question, why do members of specific discourse communities use the language the way they do? The author is sure that the answer takes into account not only socio-cultural but 
cognitive factors too, thereby attempting to clarify not only the communicative goals of the discourse community in question but also the cognitive strategies employed by its members to achieve these goals [5: 629]. Let us consider the term "genre". J. Swales in his famous definition refers to a "genre" as a "class of communicative event" in which its communicative purpose is shared by specific discourse community members [15:58]. V.K. Bhatia writes: "Genre is a recognizable communicative event characterized by a set of communicative purpose(s) identified and mutually understood by the members of the professional or academic community in which it regularly occurs” [2: 13]. The researcher goes on saying: “...the genre is primarily characterized by the communicative purpose that it is intended to fulfil. Any major change in the communicative purpose is likely to give us a different genre; however minor changes or modifications help us distinguish sub-genres" [2:13]. According to V.K. Bhatia, three interrelated elements of a genre are: communicative purpose, moves and rhetorical strategies which help obtain the desired goal.

J. Harmer defines a genre as "a type of written organization and layout (such as an advertisement, a letter, a poem, a magazine article, etc.) which will be instantly recognized for what it is by members of a discourse community, that is any group of people who share the same language customs and norms" [11:31]. V.B. Bhatia states: "In the present-day competitive academic and professional climate, genres are seldom seen to maintain static values but have become vehicles for a more complex and dynamic exchange of information, resulting in constant mixing of a variety of somewhat independent generic values within the more standardized genres” [6: 182]. Analyzing the role of a genre analysis V.K. Bhatia connects the linguistic analysis of a genre with its application in foreign language teaching and stresses: "In recent years, genre analysis has established itself as an important field of study, having implications for applied linguistics, especially in the teaching and learning of languages, mass communication, writing research, language reform and a number of other areas related to professional and academic communication” [4:313]. According to V.K. Bhatia, genre analysis is the study of situated linguistic behavior in institutionalized academic or professional settings, whichever way one may look at it [5: 629]. This definition reveals some aspects of genre theory: types of rhetorical action, which gives individual genres their integrity; regularities of social processes, which form the peculiarities of a genre; 
and consistency of communicative purposes which makes possible the propensity for innovation coming from the essentially dynamic nature of a genre [5: 630]. The researcher points out three crucial cornerstones of any genre: a) recurrence of rhetorical situations; b) shared communicative purposes and c) regularities of structural organization. The first cornerstone relates to socio-cultural context and is based on the belief that all discourse forms are socially determined [5: 641]. The author highlights the idea that oral and written communications are efficient if only all the participants share, not only the code, but also the knowledge of the genre, which includes the knowledge of its construction, interpretation and use [5: 646]. Speaking about the implications for language teaching V.K. Bhatia is sure that teachers may use applied genre analysis for innovative exploitation of language resources within a particular professional setting [5: 648]. J. Swales in 1981 [14] and in 2004 [16] developed his famous CREATE - A RESEARCH - SPACE (or CARS) Model on the basis of a scientific article analysis. This model consists of moves and steps which are considered to be the main structural constituents of a genre. The move is "a rhetorical unit that performs a coherent communicative function" [16: 228-229]. The combination of moves reveals structural patterns of the rhetorical discourse and their sequence which is based on the author's communicative goals. J. Swales in "Genre Analysis" theorizes on the concept of genre for research and teaching. The researcher also notes that the move-based model is common to all academic disciplines and different steps may be used in different disciplines [5: 58]. V.K. Bhatia continues his studies and the next genre to be analyzed is an advertising letter in which the author asks for a grant. The scholar proposes a 6 - move structure. The moves include: 1. Establishing credentials. 2. Introducing the cause. 3. Offering incentives. 4. Enclosing brochures. 5. Soliciting support. 6. Expressing gratitude. The researcher states that the analysis "has been based on a limited set of data from a specific cultural content. A more informed discussion ... will require a more comprehensive, rigorous, and sustained analysis of data” [3: 110]. Studying the discourse of a letter asking for grants, V.K. Bhatia claims that this discourse represents one of the most dynamic forms of language use. For a relatively limited number of communicative functions, this discourse form offers a large variety of creative options, some rarely used before. It is a category of genre that offers an interesting and challenging profile of linguistic realization to 
achieve a limited set of generic objectives [3: 100]. Discourse in teaching foreign languages is used to teach real-life interaction: "Recent work in genre theory indicates a strong shift of emphasis from text to context... The analysis is becoming increasingly multidisciplinary, in that specific disciplinary concerns and methodologies are getting reflected in analytical frameworks, thus integrating professional and disciplinary practices with discursive practices of the professional and disciplinary communities. This integration of discursive and professional practices has made genre analytical insights more relevant and acceptable to the disciplinary and professional communities, which is also a useful development for applications of the theory, especially in English for Special Purposes (ESP) and Professional Communication practices” [7: 166].

Linguistic analysis of a medical discourse which is focused on lexical, grammatical, functional and rhetoric peculiarities of a written or an oral discourse appears to be very fruitful allowing us to answer the questions how tests are structured and organized. J. Harmer is sure that textual success often depends on the familiarity of text organization for readers of the discourse community, however small or large that community might be and students should be aware of the genre norms [11: 32]. Speaking may be the most crucial of all four types of speech activities and a lot of our learners are primarily interested in acquiring an ability to speak. Dealing with professional medical genres we assume that every genre is clearly structured and has its own sets of language structures. The task of language instructors is to acquaint the learners with existing genre norms.

This especially concerns the genre of an oral representation of a medical history. The constituents of oral presentation are not obligatory components, they are changeable and may be omitted. Let us consider a situation when a patient was admitted to hospital into the emergency department. The oral presentation of the patient's medical history may have such a multi-move structure: 1. Previous occupation. 2. Initial symptoms. 3. Initial diagnosis (if known). 4. Condition immediately prior to admission. 5. Reason for emergency admission. 6. Past history of a patient's disease (information about relatives' diseases, style of patient's life, his/her habits, conditions of living and working). Following this division, we may suggest such sets of linguistic means with these "moves" (subtitles): Occupation. What is your surname and first name? When were you born? How old are you? Where do you live? 
What's your home address? Where do you work? Are you married? Do you have disabilities? Are you an old-age or disability pensioner? Do you have any children? What's your occupation? Do you stay on your feet for a long time during your working day? Initial symptoms. When did the first symptoms appear? How did it all start? Have you had these symptoms for a long time? What do you complain of now? Initial diagnosis. When was your diagnosis made? When did you fall ill? Current condition. Where do you feel the pain? Where does the pain irradiate? When does the pain appear? How long does the attack last? What relieves your condition? What medicines are effective? Do you have any accompanying factors during the attack? Does the pain appear under at rest or during exercise? Past history. Have you ever been admitted to hospital? Have you ever had (headaches) before? Have you had any changes in your health since your last visit to a doctor? Family history. Are your parents alive? What did your father die of? How old was he? Who in your family suffers from a similar problem?

When a patient is speaking about hypertension symptoms, he / she can't but use such words and expressions: headache, dizziness, heart beating, nausea, vomiting, insomnia, fatigue, edema (swelling) of legs, noise in the ears, severe pains in the heart, acute pains in the sternum. When the diagnosis is gastritis, these words and expressions are: belching, eructation, heartburn, hiccup, diarrhea, hunger pains, cramps, etc.

The task of a teacher is to simulate the environmental settings and to cover an information gap which emerges when a student presents a medical history orally and a teacher wants to elicit a feedback from the other students. According to K. Bailey, activities "involving information gaps can be used at all levels of instruction to create communicative needs and motivate interaction" [1:129]. We can suggest some meaningful activities for implementation of this task. Some students (A, B and C) take turns speaking about medical histories of different patients. They are asked to be patient-centered and ask open questions. Learners may use different texts from their course-book for presenting medical histories. These pieces of written discourse may represent: a letter from a GP (general practitioner) to a consultant when a GP asks for the opinion and advice [9: 10], doctor's findings after patient's examination [9:9], an interview between a doctor and a patient, a letter of referral [9: 20], a discussion between a GP and a consultant [9: 22], a conversation between two doctors [9: 23], a 
checklist for the first examination of a patient [9: 32], a list of investigation for a patient [9: 52], etc. If some pieces of information are omitted, the learners fill in the gaps [9: 11]. The other students (D, E and $\mathrm{F}$ ) give feedback about these oral presentations of medical histories. They are writing down some notes when they are listening to students A, B, C presenting their medical histories, and decide whether the patients are at risk or not. Students work in teams. They discuss clinical cases which have been presented orally, and then they may be asked to give examples from their own or their group mates' experience, bearing in mind confidentiality, as some researchers state that the activities referring to the events from the students' lives have proved their effectiveness in a language teaching [8: 4].

Concerning register study, we should state that the passive voice is used much more frequently than in general English.

We agree with J. Harmer's statement that "in communicative activities there are stages where communication is more important than accuracy” [11: 49].

The teacher's role as a facilitator is not to interrupt a student occasionally but to facilitate a life situation in a classroom, if possible, summarize the mistakes which may have occurred more than once, correct and explain them only after the learner's presentation.

Now let us consider the genre of a scientific text for the specialty “Technologies of Medical Diagnosing and Treatment". The task of a teacher is to instruct the students to use the necessary sets of vocabulary and grammar structures, to master coping with enormous amount of words and their usage in the appropriate situations of the domain of laboratory diagnosing. It is very important to include into the syllabus the topics and information content which reflect a real-life interaction between a doctor and a laboratory scientist which occurs in a medical environment. The principle of system approach is very important in this work. It means that all the units of the course-book for the students of the specialty “Technologies of Medical Diagnosing and Treatment" (Master's level) should be systematized concerning the content and the structure. Forms and methods should be diverse and rational preserving the major guidelines of three-stage work (pre-reading stage, whilereading stage and post-reading stage) aiming at the final educational goal and perspective: students' oral practice. Let us see how this purpose can be implemented with the learners studying laboratory medicine while working on scientific texts. 
While studying scientific texts with the students of the specialty “Technologies of Medical Diagnosing and Treatment" it is advisable and preferable to follow the scheme of two-move hierarchy. It presupposes not only the work on the text describing the disease being studied but also the follow-up with a Case study associated with this condition.

We are going to analyze the work on the text "Myeloproliferative neoplasm" [17: 94] and the Case study "Multiple Myeloma: The Case of the Disappearing Band" [12]. The texts deal with laboratory diagnosing and hematology. The curriculum and the syllabus for the specialty "Technologies of Medical Diagnosing and Treatment" presuppose the knowledge about etiology, epidemiology, clinical presentation, pathophysiology, symptoms and development of the diseases that are included into the syllabus. It is helpful for the students to discuss peculiarities of the myeloproliferative neoplasm while examining the case study of the multiple myeloma. "The proficiency of the specialty "Technologies of Medical Diagnosing and Treatment" covers not only the ability to perform and analyze the performed tests but also consult the doctors-colleagues on the nature and dynamics of specimens and test results” [17: 117].

The case study includes clinical history (a 64-year old African American man), chief complaint (chest pain), history of present illness. The patient had a chest pain which didn't radiate anywhere and began 4 days ago. He also reported problems with breathing, chills, fatigue, headache, and nausea. He lost $3.63 \mathrm{~kg}$ in weight. Electrocardiogram showed no abnormality in the sinus rhythm [12]. The patient had the major tests and investigations performed. The bone marrow biopsy was made and its results can also be a subject of discussion and consultations. The patient hadn't been allergic to anything in his life. The information that his parents were ill with malignancies in the chest and throat was also included into the Case study. Tobacco intake was one pack per week. The physical examination was also made.

In the text it is stated that myeloproliferative neoplasm (MPN) is one of the primary types of the myeloid malignancies which can be subdivided into some conditions. There are three stages of this disease. In the text the chronic phase is discussed [17: 117]. During the prereading stage students study the words: malignancy, common, onset, to define, to accelerate, to preserve, immature, persistent, ration, and significant. 
The learners have to fill in the gaps in two columns that comprise only nouns and only verbs (the words are partially given): to differentiate, classification, observation, description, diagnosis, and transformation.

During the while-reading stage the students analyze (give EnglishEnglish description) the words: neoplasm, leukemia, leukocyte, leukocytosis and decode the abbreviations: $M P N, C M L$, and $W H O$ (myeloproliferative neoplasm, chronic myelogenous leukemia, World Health Organization).

At the post-reading stage the students answer the questions to the text:

1. How is the myeloproliferative neoplasm classified? 2. What is CML? 3. How is CML defined? 4. Who was the first to describe the Philadelphia chromosome? 5. At what phase is the disease diagnosed? 6. What are the patients' symptoms? 7 . How long does the chronic phase last? 8. What is the presence percentage of the Philadelphia chromosome in cases of CML? 9. What can the BCR-ABL1 fusion gene be detected by? 10. What are the characteristics features of bone marrow examination (chronic phase)? and complete the sentences: 1. The myeloproliferative neoplasm is ... 2. Chronic myelogenous leukemia is observed in ... 3. CML is characterized by the presence of ... .4. The Philadelphia chromosome is ... 5. CML is diagnosed in ... 6. CML may last for ... .7. In the chronic phase blast population is up to ...

Task "True / False" is as usual highly effective at the post-reading phase. Students should state if these statements are true or false:

1. At the chronic phase increased myeloid cells to erythroid cells ratio is less than 10:1. 2. The myeloproliferative neoplasm is a myeloid malignancy. 3. The onset of CML is observed in the third decade of life. 4. The Philadelphia chromosome was first described in 2000.

The oral activity is represented by the task to search for the Internet to get the information about one of the similar diseases (acute leukemia).

In the first part of the Case study "Multiple Myeloma: The Case of the Disappearing Band" [12] the students study the words, answer the questions, complete the sentences, describe the clinical history of the patient in writing and role-play the situation when they present the case study at a scientific conference. In the second part of the Case study the students analyze which diagnosis is the most likely for this patient, how 
a normal plasma cell becomes a myeloma-propagating cell and what the appropriate specimen collection and handling for serum protein electrophoresis and immunofixation are.

The students are asked to search on the Internet to get the information to determine the nature of the phantom band. The text of the Case study "Multiple Myeloma: The Case of the Disappearing Band" [12] comprises a subtitle "Possible answers which solve all these issues. At the while-reading stage two terms are analyzed: immunoglobulin and hyperdiploidy. The three terms are encoded: IGH, SPE, IFE (the keys: immunoglobulin heavy chain, serum protein electrophoresis, immunofixation electrphoresis). The post-reading stage comprises some tasks, one of which is to say who asks the given questions: a doctor or a laboratory scientist.

Let us consider some letters of referral from a doctor to a consultant. The first letter [2: 20-21] includes such moves: 1. Request for an advice. 2. Previous history of the disease. 3. Symptoms of the current condition (kind of attacks of chest tightness, pain location, attacks duration, accompanying signs, family history of the disease on the father's side). 4. Cigarette intake. 5. Findings on a physical examination (results of a visual examination). 6. Physical examination of the organ where the pain is localized (enlargement of the liver). 7. Previous treatment.

The second letter of referral contains such moves: 1. Request for assessment of the patient's state. 2. Past history of the disease. 3. Previous complaints. 4. Results of the urine test. 5. Analysis of the patient's emotional state (his relationships with his girlfriend). 6. Previous medications. 7. Side effects of previous medications. 8. Current symptoms. 9. Current medication.

The description of the patient's physical state is very detailed in the first letter of referral. The doctor states his build, the form of the chest, the regular character of the pulse, the patient's blood pressure, the edema on the ankle, and results of the detailed examination of the chest [2: 20-21]. The letter of referral in the second example is much shorter but it contains a pre-form. The author proposes to fill in the admission form where the information about the patient is presented in the table: patient's name, age, siblings, relevant family medical history, purpose of referral, presenting symptoms, BMI, past treatment, and present medication.

Analyzing both registers we should state that the passive voice is used very often: "These fears are based on the fact", "...he had to be 
sedated", “...become engaged”, “...he has been treated”, "Heart sounds were closed...", "He was given...".

Such vocabulary items are more likely to occur in medical academic writing than in general contexts: on exertion, productive cough, pain radiating to, upper right arm, whooping cough, wheezy bronchitis, pulmonary tuberculosis, barrel-shaped chest, peripheral cyanosis, jugular venous pressure, liver dullness, and right costal margin. The usage of such an expression as "finger clubbing" is interesting here as dictionaries do not state its meaning "enlargement of fingers", "fingers' swelling" and students may find it difficult to translate.

It will be efficient before starting the work on the letter of referral to ask students to discuss what they would predict to find in the letter of referral when a physician refers a patient to a specialist at a hospital. Students read the letter and check their answers. The teacher may propose the students a list of diseases a patient may suffer from and ask them to choose the relevant disorder (Does the patient suffer from diphtheria, flu, hepatitis, measles, meningitis, mumps, pertussis, smallpox, tetanus, diarrhea, jaundice, etc.?).

Conclusions. To start with, the authors have made a thorough analysis of the theory of genres, having presented different descriptions of a genre. Besides, the researchers have shown how the theory of genre can work in tackling a professional discourse in a language medical classroom and the cohesion between different medical genres.

Furthermore, it has been stated that medical discourses are commonly used in academic medical settings. Every genre is ruled by specific regularities of its structural organization. All discourse forms are socially determined, that is, people from a definite group (users of a specific genre) know which grammar and lexical constructions they should apply in order to have an effective interaction. The medical discourse should be structured in subdivisions ("moves") which are needed in order to succeed in implementing educational and professional tasks in a medical community. The work on medical discourses that have been analyzed requires a thorough pre-reading, while-reading and post-reading activities. The course-books for medical students should include different information gap activities.

Moreover, the authors have singled out the "moves" of the three genres and developed the sequence of meaningful pre-reading, whilereading, post-reading and information gap activities which are effective while working on the discourses that have been studied. The necessary 
sets of linguistic means and vocabulary items which are used in order to be effective in a language medical environment have been defined.

In handling a genre of an oral presentation of a medical history the authors have come to the conclusion that all the constituents are not obligatory, as they are changeable and may be omitted. The students may present different pieces of a written discourse while working on the presentation of a patient's medical history. Concerning the language register, the authors state that the passive voice is more commonly used than in general English.

For the genre of a scientific text for the specialty "Technologies of Medical Diagnosing and Treatment” a scheme of two-move hierarchy has been proposed: the text describing etiology, epidemiology, clinical presentation, symptoms and the course of a disease and a Case study associated with this condition.

Finally, the authors have singled out the constituents (the "moves”) of a letter of referral, characterized the register of the genre and have developed some activities for implementation the guidelines of the theory of genre into efficient teaching English to medical students.

The perspectives of further research will concern the analysis and functioning of the genre of informative poster in speech. We consider that the usage of this genre for educational objectives will facilitate the implementation of the course tasks and develop students' proficiency in the field of mastering a foreign language and in the domain of their professional habits and skills which the future medical specialists will use in work environments and interaction.

\section{LITERATURE}

1. Bailey K.M. Practical English Language Teaching: Speaking. Mc Graw Hill, 2005. 199 p.

2. Bhatia V.K. Analyzing Genre: language use in professional settings. London: Longman, 1993. 246 p.

3. Bhatia V.K. Generic Patterns in Fundraising Discourse. New Directions for Philanthropic Fundraising. 1998. 22. P. 95-110.

4. Bhatia V.K. Genre Analysis and World Englishes. World Englishes. Blackwell Publishers, 1997. Volume 16, Issue 3. P. 313-319.

5. Bhatia V.K. Genre Analysis Today. Revue belge de Philologie et d'Histoire. 1997. 75-3. P. 629-652.

6. Bhatia V.K. Genre - Mixing in Academic Introductions. English for Specific Purposes. 1997. Volume 16, Issue 3. P. 181-195. DOI: https://doi.org/10.1016/S0889-4906(96)00039-7. 
7. Bhatia V.K. Towards Critical Genre Analysis. Advances in Discourse Studies. Psychology press, 2008. 3 / 10. P. 150-186.

8. Dudley-Evans T., Saint John M.J. Developments in English for Specific Purposes: a multi -disciplinary approach. Cambridge: Cambridge University Press, 1998. 301 p.

9. Glendinning E.H. English in Medicine. Cambridge: Cambridge University Press, 2015. $153 \mathrm{p}$.

10. Grice T. Oxford English for Careers. Nursing 2. Student's Book. Oxford: Oxford University Press, 2018. 135 p.

11. Harmer J. The Practice of English Language Teaching. Fourth edition. Harlow: Pearson Education Limited, 2007. 448 p.

12. Mamone L, Jones J, Shiguang L. Multiple Myeloma: The Case of the Disappearing Band. Laboratory Medicine. Volume 49, Issue 1, February 2018. P. 87-91. URL: https://academic.oup.com/labmed/pages/selected_ case_studies_2018 (accessed 12.12.2019). DOI: https://doi.org/10.1093/ labmed/lmx045.

13. Nagy W.E. Teaching Vocabulary to Improve Reading Comprehension. Newark: International Reading Association, 2003. 43 p.

14. Swales J.M. Aspects of Article Introductions. Aston ESP Research Report No 1. Language Studies Unit. Birmingham: University of Astonin, $1981.95 \mathrm{p}$.

15. Swales J.M. Genre Analysis: English in academic and research settings. Cambridge: Cambridge University Press, 1990. 260 p.

16. Swales J.M., Feak C.B. Academic Writing for Graduate Students: Essential tasks and skills. Ann Arbor: University of Michigan, 2004. 282 p.

17. Wahed A., Dasgupta A. Hematology and Coagulaion. A Comprehensive Review for Board Preparation, Certification and Clinical Practice. Oxford: Elsevier Inc, 2015. 305 p.

\section{REFERENCES}

Bailey, K.M. (2005). Practical English Language Teaching: Speaking. Mc Graw - Hill [in English].

Bhatia, V.K. (1993). Analyzing Genre: language use in professional settings. London: Longman [in English].

Bhatia, V.K. (1997). Genre Analysis and World Englishes. World Englishes. Blackwell Publishers. Volume 16, Issue 3, pp. 313-319 [in English].

Bhatia, V.K. (1997). Genre Analysis Today. Revue belge de Philologie et d'Histoire. 75-3, pp. 629-652 [in English].

Bhatia, V.K. (1997). Genre - Mixing in Academic Introductions. English for Specific Purposes. Volume 16, Issue 3, pp. 181-195 [in English]. DOI: https://doi.org/10.1016/S0889-4906(96)00039-7.

Bhatia, V.K. (1998). Generic Patterns in Fundraising Discourse. New Directions for Philanthropic Fundraising. 22, pp. 95-110 [in English]. 
Bhatia, V.K. (2008). Towards Critical Genre Analysis. Advances in Discourse Studies. Psychology press. 3 / 10, pp. 150-186 [in English].

Duddley-Evans, T. and Saint John, M.J. (1998). Developments in English for Specific Purposes: a multi-disciplinary approach. Cambridge: Cambridge University Press [in English].

Glendinning, E.H. (2015). English in Medicine. Cambridge: Cambridge University Press [in English].

Grice, T. (2018). Oxford English for Careers. Nursing 2. Student's Book. Oxford: Oxford University Press [in English].

Harmer, J. (2007). The Practice of English Language Teaching. Fourth edition. Harlow: Pearson Education Limited [in English].

Mamone, L., Jones, J. and Shiguang, L. (2018). Multiple Myeloma: The Case of the Disappearing Band. Laboratory Medicine. Volume 49, Issue 1, February 2018, pp. 87-91. Available at: https://academic.oup.com/labmed/ pages/selected_case_studies_2018 [Accessed 12 Dec. 2019] [in English]. DOI: https://doi.org/10.1093/labmed/lmx045.

Nagy, W.E. (2003). Teaching Vocabulary to Improve Reading Comprehension.

Newark: International Reading Association [in English].

Swales, J.M. (1990). Genre Analysis: English in academic and research settings. Cambridge: Cambridge University Press [in English].

Swales, J. (1981). Aspects of Article Introductions. Aston ESP Research

Report No 1. Language Studies Unit. Birmingham: University of Astonin [in English].

Swales, J.M., Feak, C.B. (2004). Academic Writing for Graduate Students: Essential tasks and skills. Ann Arbor: University of Michigan [in English].

Wahed, A. and Dasgupta, A. (2015). Hematology and Coagulaion. A Comprehensive Review for Board Preparation, Certification and Clinical Practice. Oxford: Elsevier Inc [in English].

Стаття надійшла до редакиії: 15.01.2020

Козка Ірина Кирилівна, канд. філол. наук, доцент кафедри мовної підготовки іноземних громадян Харківського національного медичного університету (61022, Харків, проспект Науки, 4); e-mail: iryna.kozka@gmail.com; orcid: http://orcid.org/0000-0002-2414-0249.

Козка Ирина Кирилловна, канд. филол. наук, доцент кафедры языковой подготовки иностранных граждан Харьковского национального медицинского университета (61022, Харьков, проспект Науки, 4); e-mail: iryna.kozka@gmail.com; orcid: http://orcid.org/0000-0002-2414-0249.

Iryna Kozka, $\mathrm{PhD}$ in Philology, Associate Professor, Language Training Department for Foreign Citizens, Kharkiv National Medical University (61022, Kharkiv, 4 Nauky Avenue); e-mail: iryna.kozka@gmail.com; orcid: http://orcid.org/0000-0002-2414-0249. 
Краснікова Світлана Олександрівна, канд. філол. наук, професор, завідувач кафедри мовної підготовки іноземних громадян Харківського національного медичного університету (61022, Харків, проспект Науки, 4); e-mail: s_krasnikova@ukr.net; orcid: http://orcid.org/0000-00027155-4436.

Красникова Светлана Александровна, канд. филол. наук, профессор, заведующий кафедрой языковой подготовки иностранных граждан Харьковского национального медицинского университета (61022, Харьков, проспект Науки, 4); e-mail: s_krasnikova@ukr.net; orcid: http:// orcid.org/0000-0002-7155-4436.

Svitlana Krasnikova, PhD in Philology, Professor, Head of the Language Training Department for Foreign Citizens, Kharkiv National Medical University (61022, Kharkiv, 4 Nauky Avenue); e-mail: s_krasnikova@ukr.net; orcid: http://orcid.org/0000-0002-7155-4436. 